\title{
SocArXiv
}

Preprint : August 21, 2019

URL/DOI GOES HERE

\section{Multilevel Simulation of Demography and Food Production in Ancient Agrarian Societies: A Case Study from Roman North Africa}

\author{
Nicolas Gauthier \\ University of Arizona
}

\begin{abstract}
Feedbacks between population growth, food production, and the environment were central to the growth and decay of ancient agrarian societies. Population growth increases both the number of mouths a society must feed and the number of people working to feed them. The balance between these two forces depends on the population's age structure. Although age structure ultimately reflects individual fertility and mortality, it is households that make decisions about the production and consumption of food, and their decisions depend on interactions with all other households in a settlement. How do these organizational levels interact to influence population growth and regulation? Here, I present a multi-level agent-based model of demography, food production, and social interaction in agricultural societies. I use the model to simulate the interactions of individuals, households, and settlements in a food-limited environment, and investigate the resulting patterns of population growth. Using Roman North Africa as a motivating example, I illustrate how abstract properties like "carrying capacity" emerge from the concrete actions and interactions of millions of individual people. Looking forward, bottom-up simulations rooted in first principles of human behavior will be crucial for understanding the coevolution of preindustrial societies and their natural environments.
\end{abstract}

Keywords: agent-based modeling, food-limited demography, agricultural decision-making, carrying capacity.

\section{Introduction}

The combined forces of population growth and food production transformed global and regional environments throughout the Holocene (Kaplan et al. 2009; Hunt and Rabett 2014; Klein Goldewijk et al. 2017; Wright 2017; Roberts et al. 2019). Expanding populations made significant downstream impact on natural biogeophysical and biogeochemical cycles through 
deforestation, irrigation, and agropastoral land use (Kaplan et al. 2010; Fuller et al. 2011; He et al. 2014; Koch et al. 2019). Likewise, climate variability has influenced the growth and decline of human societies, (Benson et al. 2007; Kaniewski et al. 2013; Bevan et al. 2017; Nooren et al. 2018), although this relationship is neither simple nor constant in space and time (Danti 2010; Dunning et al. 2013; Shennan et al. 2013; Lawrence et al. 2016). Understanding the nature of two-way feedbacks between climate and society requires first closing the loop between demography, food production, and climate (Dean 1996; Butzer 2012; Bevan et al. 2017).

The feedback between a population's food supply and its health and well-being is the essential mechanism of population regulation in humans (Lee 1987; Wood 1998). Populations will grow until they reach a stable state where births equal deaths and growth stops: the demographic saturation point (Wood 1998). Long-run changes in population will arise only from changes in this point (Boserup 1965; Wood 1998). Famines, epidemics, and other catastrophic mortality events that do not change this point can lead to increased growth by reducing population pressure Watkins1985. Related to, but distinct from, the demographic saturation point is the idea of environmental "carrying capacity" or the maximum population supportable by food production in the local environment (Dewar 1984). The key variables determining environmental carrying capacity for preindustrial societies are, predictably, arable land area and potential agricultural productivity (Fanta et al. 2018a). However, "carrying capacity" varies not only across environments but also among different cultures and time periods (Currie et al. 2015). Farmers can invest their time in building terraces or irrigation infrastructure, constructing local agricultural niches and consequently raising the local carrying capacity (Lansing and Fox 2011; Bevan et al. 2013; Kaptijn 2015; Wilkinson et al. 2015). The result is a two-way feedback; population size depends on carrying capacity and carrying capacity depends on population size. How do these factors interact?

We can close this feedback loop by defining the demographic saturation point as a function of the productive capacity of the entire society, integrating social, ecological, and technological factors (Wood 1998). A population's age structure is particularly important here not only because it constrains its food needs and sensitivity to food shortfalls, but also the proportion of the population capable of producing food in the first place. By explicitly modeling the interaction between population age structure, productive capacity, and vital rates, we can predict the nature and timing of population growth and regulation (Lee and Tuljapurkar 2008; Puleston and Tuljapurkar 2008; Puleston et al. 2014). One factor such models tend to leave out, however, is the nested organization of human groups.

Like many complex systems, real-world human populations are organized in nested hierarchies (Simon 1962). People act and interact within groups of varying sizes: as individuals, households, settlements, and societies. It is important to recognize this organization for understanding the population dynamics of heterogeneous human populations (Read and Leblanc 2003). While fertility and mortality occur on the individual level, decisions about food production, storage, and consumption often occur at the household level, and spatial organization of production is often determined at the settlement level. This modular organization can have major consequences for the underlying population dynamics (Chayanov 1986; Wood 1998). How might we incorporate this organizational complexity into models of food-limited demography?

To address this gap, I present a hierarchical simulation framework (Figure 1) for modeling food-limited predindustrial populations. I use a multilevel agent-based model to capture 


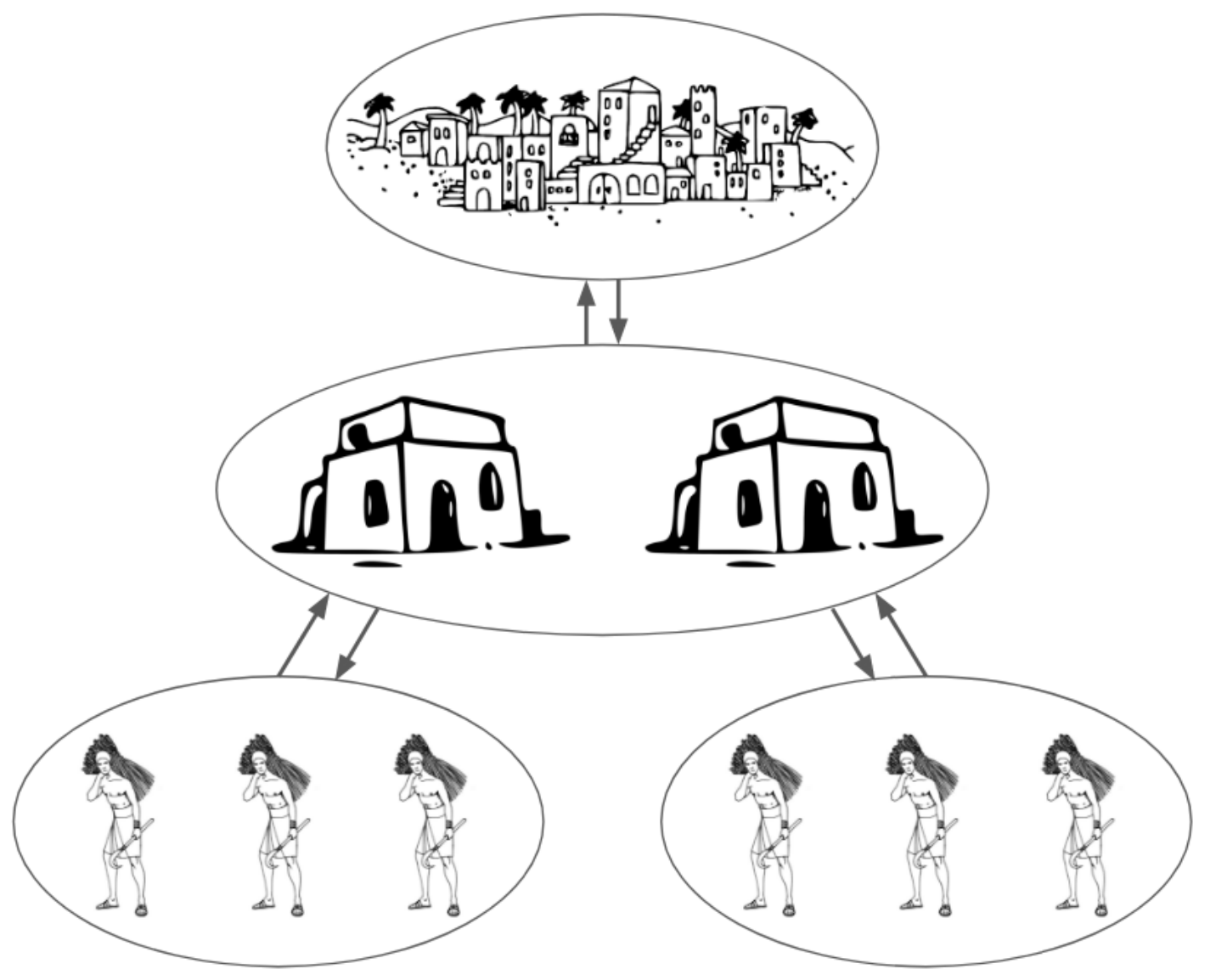

Figure 1: Hierarchy of agent decision making. Individuals are grouped into households, which are in turn grouped into settlements. Demography occurs at the individual level, but is influenced by the household, land use occurs at the household level, and land use and social interaction occurs at the settlement level.

the hierarchical organization of agricultural societies, resolving dynamics on the individual, household, and settlement scales as well as interactions across scales. The complexity of such models arises from the interaction of simple agents with heterogeneous information, objectives, and resources. One difficulty with agent-based modeling is that simulating the perceptions and decision-making of millions of interacting agents can quickly become computationally intractable. However, a multilevel simulation model selectively varies the level of abstraction to capture complex, cross-scale feedbacks in a population of millions of agents with limited computational overhead. The model presented here focuses on the emergent patterns of population growth and regulation arising from individual fertility and mortality, household decision making, and interactions among households and settlements. By foregrounding the role of human decision-making in food production and population growth, the model is able to bridge the gap between environmental and demographic change.

The Roman Imperial period in North Africa serves as a motivating case study. North Africa is a region of close land-atmosphere coupling, and experienced massive population growth and land-use and land-cover change in the Roman era, driven by multiple endogenous and 
exogenous environmental and social factors. Although the present model of demography and food production is intended to be broadly applicable, it is nevertheless useful to analyze its behavior in light of a specific social, ecological, and technological context because quantities like carrying capacity or demographic saturation point are so locally contingent. Bottomup simulation of these factors can shed light on key mechanisms and interactions otherwise obscured in top-down reconstructions of past population and land use.

\subsection{Case Study: Roman North Africa}

Two millennia ago, the province of Africa Proconsularis in North Africa - roughly modern day Tunisia, Algeria, and Libya - was a breadbasket of the Roman Empire (Kehoe 1988; Garnsey 1989). Today, cereal agriculture is limited to a narrow coastal strip at the northern edge of this semiarid region (Latiri et al. 2010). The causes and consequences of this apparent shift in productivity have long been debated (Murphey 1951). Climate change seems to have played a key role, with a millennial-scale drying trend since the mid-Holocene punctuated by century-scale fluctuations driven by oceanic variability in the North Atlantic (Dermody et al. 2012). Proxies for geomorphic change during the period suggest a primary role for climate, although second-order human impacts were also apparent (Faust et al. 2004).

An alternative perspective holds that social and technological change lead to North Africa's past agricultural productivity. The Roman state and society as a whole exerted strong social and legal pressure to bring uncultivated fields under the plow and invest in agricultural infrastructure (Kehoe 1988; Stone 1997, 1998; Hilali 2013). Local niche construction via irrigation and runoff harvesting was particularly common, combining indigenous landscape management practices with the Empire's experience in large-scale hydraulic engineering (Shaw 1982; Mattingly and Hitchner 1995; Beckers et al. 2013).

Implicit in this discussion is the assumption that climate change and socio-technical innovation are mutually exclusive. Yet, natural climatic drying was supplemented by extensive anthropogenic deforestation for food and fuel production (Hughes 2011). Paleoclimate simulations have suggested that Roman-era transformation of the land surface may have itself contributed to climatic drying (Reale and Dirmeyer 2000; Reale and Shukla 2000; Gates and Ließ 2001). So was North Africa's agricultural productivity under Roman rule the result of a briefly favorable regional climate, human management of the local environment, or feedbacks between the two?

The global land-use and population hindcasts often used by the paleoclimate modeling community are ill-suited for answering such a question (Kaplan et al. 2010; Klein Goldewijk et al. 2017). This top-down approach to estimating land use at equilibrium with population density is understandable given the tradeoffs that exist in generating global syntheses, but leave much to be desired in cases such as Roman North Africa where the direction of influence is less clear. Reliance on external, fixed population hindcasts precludes estimates of the two-way feedbacks between population growth and food production.

\section{The Model}

Agent-based models are a flexible simulation tool, allowing researchers to start with first principles of human behavior and scaffold up to a more flexible treatment of diverse cultures and time periods. The core principles of this particular model are: 
1. Human population growth is food limited (Lee 1987; Wood 1998).

2. Households are the principal unit of food production and consumption (Chayanov 1986; de Sherbinin et al. 2008).

3. Humans are boundedly-rational decision makers that attempt to make "good-enough" choices given finite information and resources (Simon 1990).

For the North Africa case I added two additional assumptions: the primary food resource is wheat grown under a biennial fallowing regime, and households use infrastructure to harvest surface runoff to increase local water availability for agriculture.

The purpose of this model is to capture the essential feedbacks between food production, population growth and regulation, and the local environment in preindustrial agricultural populations. It simulates three agent types operating in a nested hierarchy: individuals, households, and settlements. Individual agents reproduce and die according to the amount of food in the household. Household agents allocate their land and labor to produce food, seeking to grow enough food to satisfy its occupant's needs while storing the surplus. Settlement agents mediate the competition for land among their constituent households, and exchange flows of food and people with neighboring settlements. I analyze the model both in the abstract, focusing on processes of population growth and regulation, and parameterized to represent the Roman Imperial period in North Africa, focusing on stable patterns of population density and agricultural productivity.

The model is implemented in $\mathrm{R}$, primarily using packages in the tidyverse paradigm. The tidyverse uses flat, potentially nested data tables as the basic computational unit and emphasizes code that is concise, expressive, and modular. Specifically, the model uses the nesting and iteration functions in the tidyr, dplyr, and purrr packages to allow for interactions across scales and seamless parallel processing. The model code itself is available as an open source $\mathrm{R}$ package, and is available for download, reuse, and modification at https://github.com/nick-gauthier/Silvanus. R's strengths as a functional programming language contrast with the object-oriented languages commonly used for agent-based modeling. The functional programming paradigm shifts the focus away from the agents themselves and towards what the agents $d o$ in the modeled world using well-documented and tested functions.

\subsection{Food-limited Demography}

Population dynamics in the model are food limited, whereby fertility and mortality rates reflect the ratio of a population's food supply to its caloric needs (Puleston et al. 2014). This food ratio acts as a negative feedback on population size (Figure 2). Population growth increases both the number of mouths to feed and the number of people working to feed them. Which of these two numbers grows faster depends on the size and age structure of the population. The food ratio falls below 1.0 when caloric demand outstrips supply, which reduces age-specific fertility and increases age-specific mortality until the population stops growing entirely. The exact mechanisms of this sensitivity (e.g. stress, starvation, fertility control, infanticide) are less important to the dynamics than their net effect on age structure (Puleston et al. 2014).

Much theoretical work in food-limited demography has relied on the population projection 


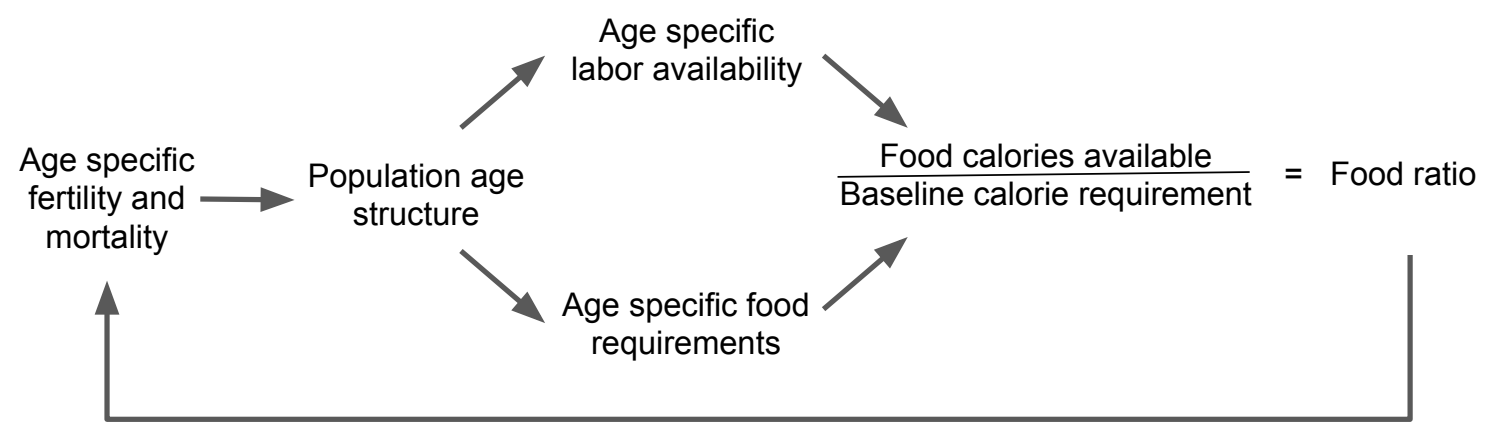

Figure 2: Food-limited demography, adapted from Puleston et al. (2014). The food ratio reflects the balance of food calories available to the calories required to support the population. The food ratio feeds back to influence these variables by altering the size and age structure of the population.

matrices used in ecology to model age-structure in populations (Lee and Tuljapurkar 2008; Puleston and Tuljapurkar 2008; Puleston et al. 2014). This approach allows for precise, analytical exploration of these models to determine features such as equilibrium age structure and demographic saturation point. Yet in order to achieve such analytical clarity the models assume continuous, well mixed populations that collectively produce and share food equal to their abilities and needs. These approaches have done much for establishing theoretical baselines for key variables and processes. But they lack the ability to incorporate complex social structure.

Here I use a discrete-time, individual-based implementation of food-limited demography. Each individual in the simulation has an age and is associated with a household. The probability of an individual giving birth or dying is a function of their age and the food available to all individuals in a household. Age-specific fertility and mortality tables and elasticities are derived from empirical syntheses (Lee and Tuljapurkar 2008). Baseline age-specific fertility and mortality data are derived from Coale-Demeny model "West" life tables (Coale et al. 1983). All individuals in a household share food equally, and decisions concerning food production and consumption are made instead on the household level.

\subsection{Household Decision-making}

The births and deaths of individual agents determine the labor availability and food requirements of their associated household. The household agent then decides what it must do to achieve those requirements. The agents represent smallholder agricultural households, producing all of their food calories from a mix of rainfed and irrigated wheat (or any staple crop). These households are boundedly rational, using local information and simple heuristics to allocate their limited land, labor, and capital.

First, a household allocates its labor between different activities. Here, its options are to spend time farming or maintaining irrigation infrastructure. Given knowledge of the irrigation system and simple heuristics for relative returns to labor farming and maintaining infrastructure, the households solve a constrained optimization problem to determine of the proportion of available time they should devote to each activity so as to maximize their ex- 


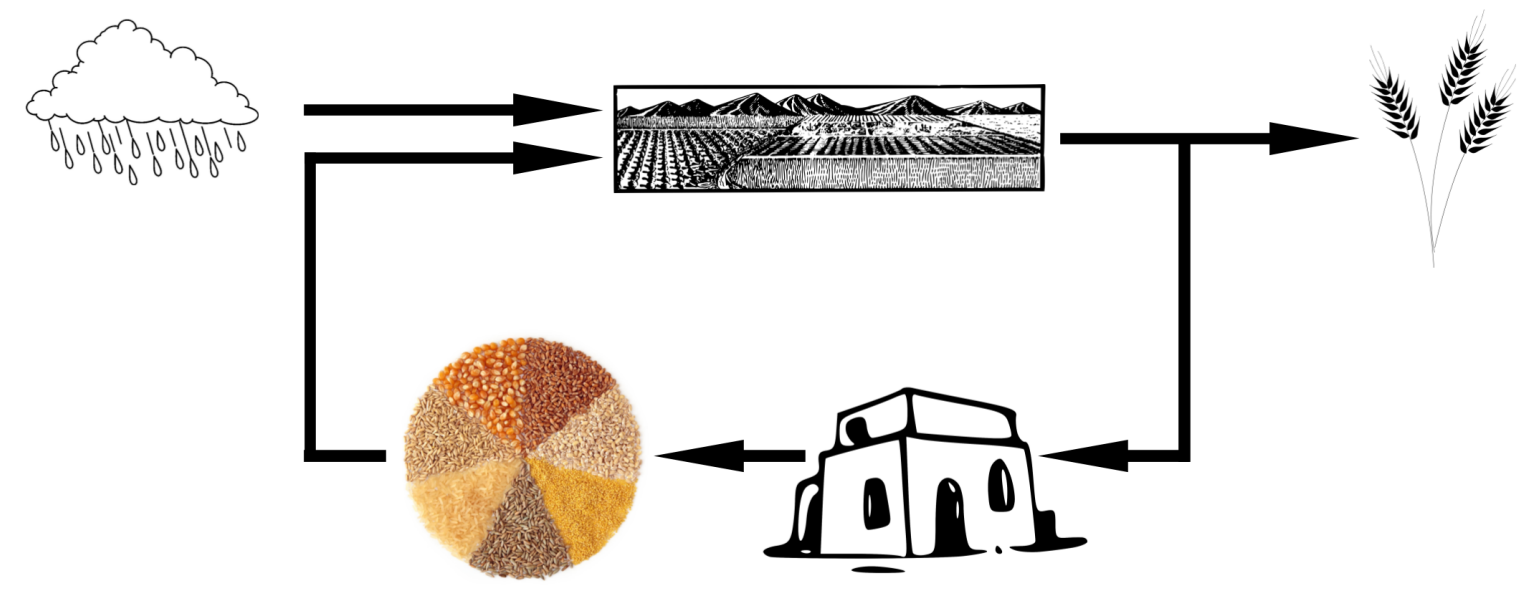

Figure 3: Conceptual diagram of household-level food production. Precipitation is the primary driver of food production, via the land surface. Households monitor crop yields and make allocate their land, labor, and capital accordingly. These decisions feed back to influence the productivity of the land surface.

pected utility (Figure 4) (Yu et al. 2015). The amount of time spent farming constrains the amount of land a household can cultivate (White 1965). The amount of time spent maintaining infrastructure determines the efficiency of irrigation, and thus the proportion of available runoff a household can direct to its fields. The performance of irrigation infrastructure is a piecewise linear function of labor inputs (Yu et al. 2015). Here, the model is parameterized to make infrastructure scalable, that is the agents can spend more or less time maintaining infrastructure and still be assured of at least some water.

Next, a household determines how much land it needs to feed its inhabitants based on the productivity of the land (Barton et al. 2012). Baseline agricultural productivity is a function of water available to crops, which reflects both annual precipitation accumulation and runoff (identical for all households in a settlement) and irrigation inputs (based on household-level infrastructure maintenance). Given this expected yield value, the household calculates the area of land required to meet its needs under a biennial fallowing regime. If this land requirement is below the household's current land holdings, then it reduces its land holdings. If more land is needed, the household will attempt to acquire it up to the limit of the total cultivable area of a settlement. If there is not enough cultivable area to satisfy the requests of all households in that settlement, then the remaining land is divided evenly.

A household then produces food on its land and consumes it. The total harvest is calculated based on the land area and crop yields and halved to account for biennial fallow. A proportion of the harvested biomass is removed to sow fields in the next year, and for taxation if necessary. Food in excess of a household's need is added to its storage, but will spoil in two years (Winterhalder et al. 2015). The household calculates its food ratio based on its stored supply as well as what remains of the current year's harvest. This new food ratio is then used to adjust the birth and death rates of the individuals living in that household according to the age-specific vital-rate elasticities discussed above. 


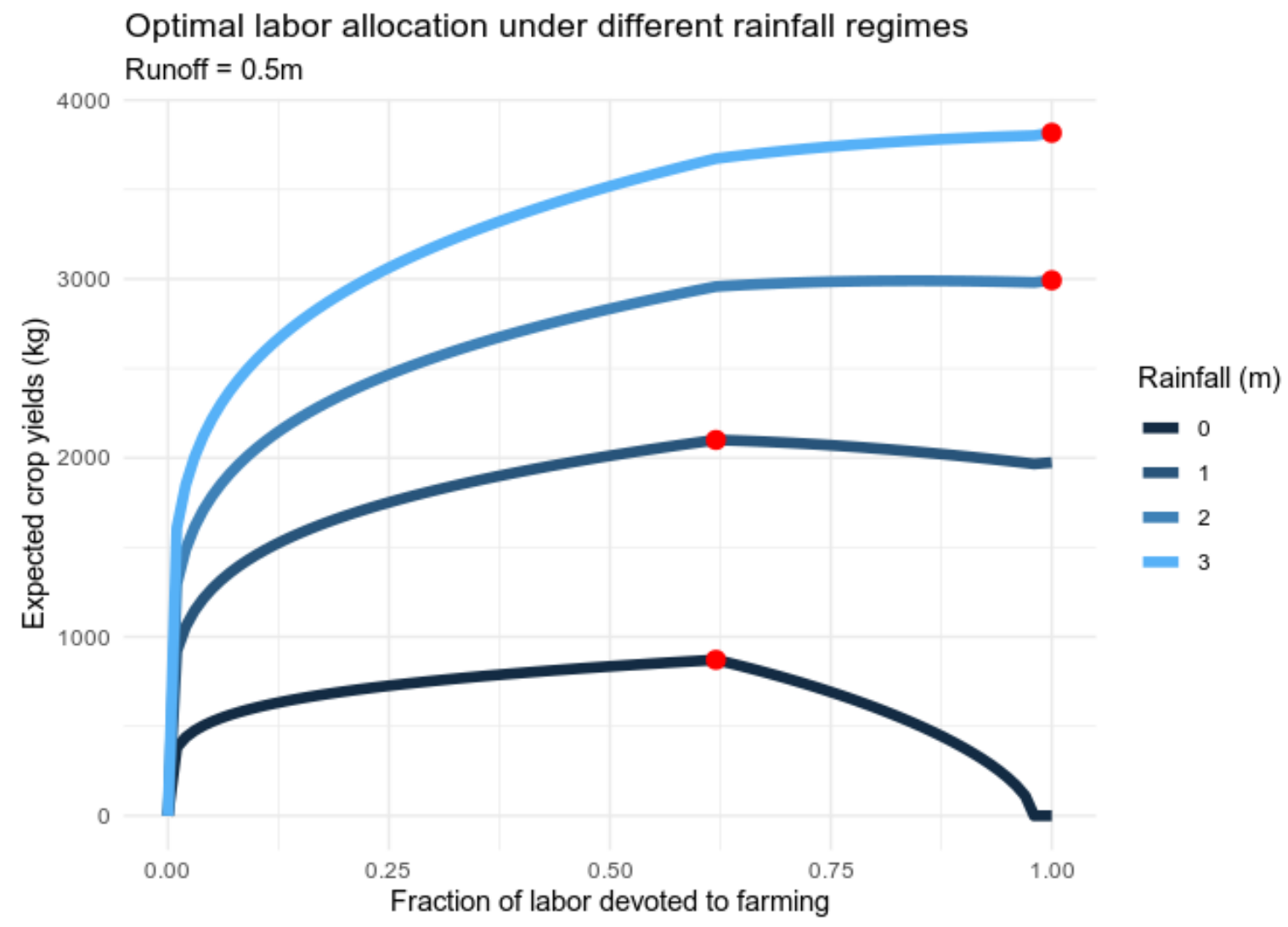

Figure 4: Household decision making as a constrained allocation problem. Households maximize their expected yields while minimizing their total labor by allocating labor to farming or irrigation. The optimal labor allocation depends on the infrastructure and the environment. Here, as an example, the amount of runoff is (unrealistically) fixed to $0.5 \mathrm{~m}$ per year and annual rainfall is allowed to vary. The fraction of labor devoted to farming versus infrastructure maintenance that maximizes the expected crop yields is highlighted in red. 
Finally, households that have grown too large may fission. The number of laborers in a household reflects the age structure of the individuals within it. For each household with more than five laborers, there is a small probability that each laborer may leave the household and start a new, single-person household. If there is enough land to support all the original occupants, then each departing individual takes an amount of land proportional to its needs from the household total. If arable land is restricted, the new household starts with no land holdings. The nature and extent of available land is determined at the settlement level.

\subsection{Land Use and Settlement Patterns}

A group of household agents combine to form a settlement agent. At the settlement scale, the model divides the landscape into a regular hexagonal lattice. Each settlement is associated with a hexagonal tile that represents the physical settlement and its associated hinterland. The locations of settlements do not change over time, only the distribution of population within settlements. A settlement is defined as the aggregate of all households in a hexagonal grid cell, and the model makes no distinction between dispersed or aggregated physical settlements within a cell. By default each hexagonal tile has a radius $5 \mathrm{~km}$ approximating the agricultural catchment within a walking distance of 1-2 hours. The model acts as a cellular automaton, with the state of each hexagon evolving over time as a function of its current state and its neighboring cells.

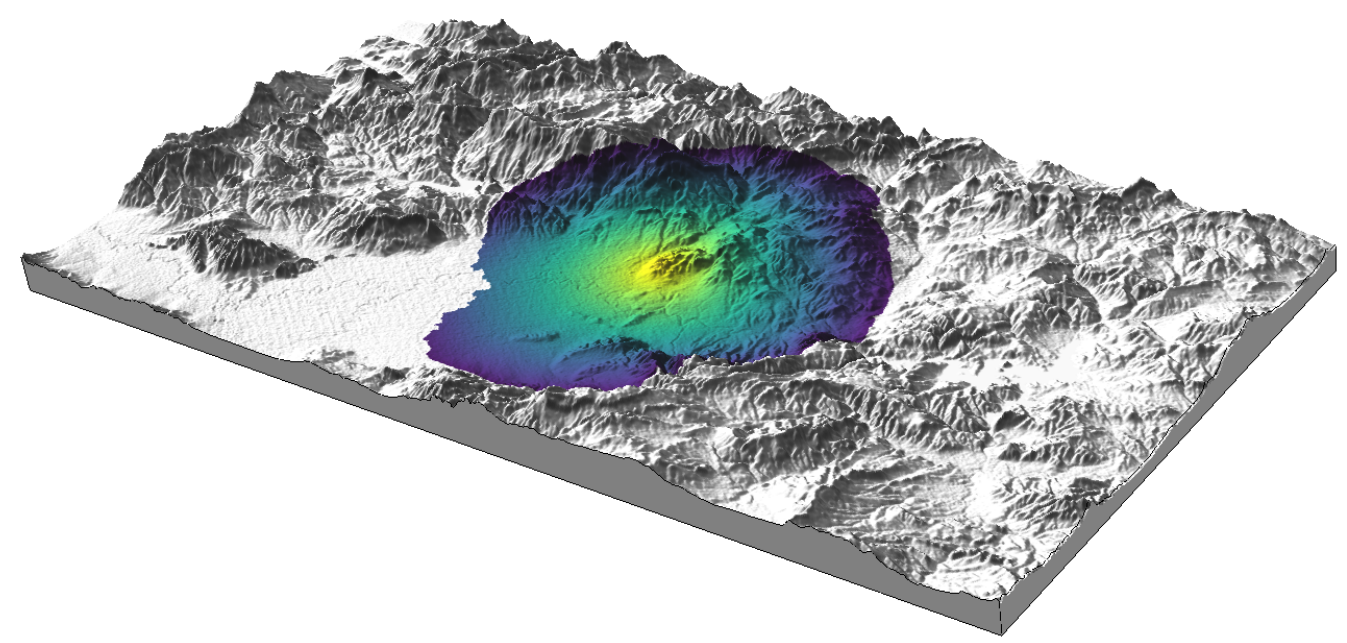

Figure 5: Example of a settlement agent and its hinterland. Fine-resolution geographic data shown here, such as distance from the settlement (color) and slope (shading), is aggregated to the tile level. Subgrid scale heterogeneity in land use and land cover types are modeled using subgrid scale "tiles", calculated as proportions of the total grid cell area.

Although the hexagonal tiling is rather coarse resolution, the model incorporates high-resolution geographic information (Figure 5). The model simulates the environment within each hexagonal grid cell using a subgrid scale tiling approach similar to that used in land surface and Earth system models (Avissar and Pielke 2002). Different land use and land cover types are conceptualized as a mosaic of "tiles" taking up a proportion of the total grid cell area, allow- 
ing for precise areal scaling of the processes associated with each. The land-use tiles include rainfed agricultural land, irrigated agricultural land, urban area, and grazing land. All except the latter type are restricted to land with less than $5^{\circ}$ slope. Wilderness land cover tiles vary by vegetation type, including barren, grass, shrub, and woodland zones.

\section{Results}

\subsection{Agricultural Populations Grow Fast When Food Is Abundant, but Quickly Reach Their Limits}

The intrinsic growth rate of a population is the potential growth rate in the absence of any form of population regulation. These growth rates are characteristic of colonists or frontier populations expanding onto a pristine landscape with abundant food. Such growth is rarely maintained for long in the real-world before population regulation brings fertility and mortality closer into alignment. Nevertheless, a population's intrinsic growth rate sets its baseline tempo of change, and constrains the speed at which a population can adjust to changes in its demographic saturation point and its resilience in face of catastrophic mortality. In the model, the intrinsic growth rate is an emergent property of the underlying individual and household dynamics, and must be estimated numerically.

I estimated the model's intrinsic growth rate by repeatedly simulating 600 years of growth among a starting population of 1525 -year-olds. The food ratio was fixed at one, so growth was unrestrained by food availability. After allowing a 300-year burn-in period to account for initial random fluctuations in the population, I estimated the growth rate as the slope of a log-normal generalized linear mixed model, with a random intercept for each replication. The average intrinsic growth rate was $1.35 \%$, with a range of $1.1-1.6 \%$.

With an intrinsic growth rate this high, food-limited populations will quickly reach their demographic saturation points. To assess the population trajectory as it approaches equilibrium, I repeated the above experiments while allowing the food ratio to vary based on food production and consumption (Figure 6). Initially, the simulated populations grow close to their intrinsic growth rate as in the food-unlimited case. At this speed, it takes only 200-300 years for an initial population of 30 reach its carrying capacity. High growth is sustained until quite late, with growth slowing only decades before growth ceases. This dynamic contrasts with the slow decline of simple logistic growth, which takes twice as long to reach carrying capacity.

The model has inherent demographic stochasticity, which influences the dynamics. When the population is small, it is very sensitive to random fluctuations. A single laborer's death could have a disproportionate impact on the food ratio of the entire household, depending on the number of dependents. As is the nature of exponential growth in the population's early phases, small initial variations can propagate forward in time indefinitely. Similarly, an initially fortuitous set of births and deaths can give a household initial advantages that become locked in via food storage and competition for land, leading to marked inequality among households as time progresses. Even when population reaches equilibrium it varies within $2-7 \%$ of the demographic saturation point. This demographic stochasticity helps to illustrate the range and role of natural, internal variability in real-world populations. 


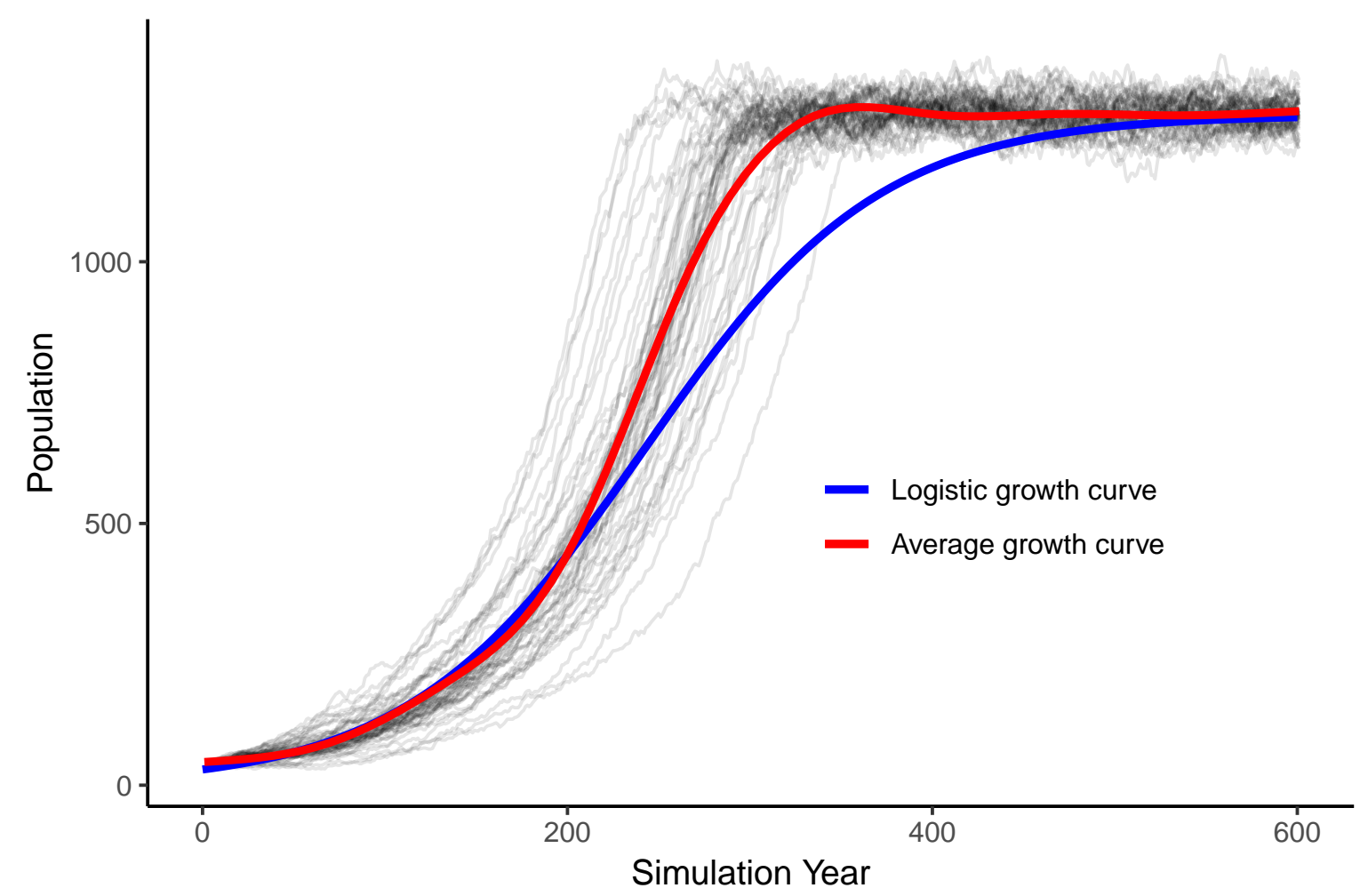

Figure 6: Population growth curves from 50 simulations under food-limited demography. Raw simulation outputs are in black, with an average curve computed using a scatterplot smoother in red. Compared to a growth curve based on logistic growth (blue), population growth continues unchecked up to a few generations before carrying capacity is reached, after which the population rapidly stabilizes. All simulations began with a population of 3025 year-olds living in a pristine agricultural landscape $10 \mathrm{~km}^{2}$ in area receiving $700 \mathrm{~mm}$ of rainfall annually. 


\subsection{Age Structure Oscillates as It Approaches Equilibrium}

A critical factor in a population's growth and regulation is its age structure, which can be summarized by the dependency ratio - the ratio of number of non-producing consumers, such as children and the elderly, to the population directly involved in food production. A population's dependency ratio is a feature of its age structure, determined by the differential fertility and mortality of individuals in different age classes. How does a population's age structure emerge from the interactions of individual demography and household level food production?

From an initial population of 25 year-olds the dependency ratio grows quickly as the founder population ages out of the labor force. The dependency ratio oscillates around its equilibrium value for several centuries, finally stabilizing at 75 in about 400 years (Figure 7). When food limitation is introduced, the equilibrium dependency ratio drops to 65 at the demographic saturation point, because the decreased food ratio increases infant mortality faster than it does for the rest of the population.

The population's fluctuating age structure as it approaches equilibrium has consequences for its response to catastrophic mortality events that selectively target individuals of certain ages. Past baby booms or busts can introduce demographic inertia, adding "memory" to the system so that external and internal disruptions propagate through several generations. This demographic inertia can also cause the population to temporarily overshoot its demographic saturation point, as it may take more than one generation before reduction in food resources is fully felt by the entire population.

\subsection{Increased Rainfall Was Key to Increased Agricultural Production in Roman North Africa}

Having explored the transient dynamics of preindustrial population growth and age structure in an abstract setting, I applied the model to a concrete case study. Was the potential agricultural productivity in Roman North Africa higher than it is today and was climate change or technological intensification the more important factor? To answer this question I ran a set of simulation experiments over a spatial domain from $5^{\circ} \mathrm{N}$ to $11.5^{\circ} \mathrm{N}$ and $34^{\circ} \mathrm{E}$ to $37.5^{\circ} \mathrm{E}$, covering portions of modern-day Algeria and Tunisia.

Each simulation was initialized by seeding all hexagonal cells in the spatial domain with 10 identical households, each containing three 25-year old individuals. From these initial conditions the model was run for 600 years, allowing the population in each grid cell to reach its stable demographic saturation point. Where water availability or cultivatable land area were not enough to sustain food production, the populations were allowed to die out without any recolonization from neighboring cells. Four scenarios were compared, with annual precipitation set to present day averages and simulated averages at $200 \mathrm{CE}$, and with and without the possibility for localized runoff-harvesting. Estimates of annual precipitation from the century bracketing $200 \mathrm{CE}$ are extracted from a previously-run paleoclimate simulation of the last 2,000 years (Jahn 2018, unpublished data). This experimental design allowed for the assessment of the degree to which climatic factors or infrastructure contributed to the possible greater agrarian population suggested for the Roman period.

Mapping the resulting equilibrium population levels from these experiments reveals North Africa's estimated agricultural carrying capacity (Figure 8). These values represent the po- 
A

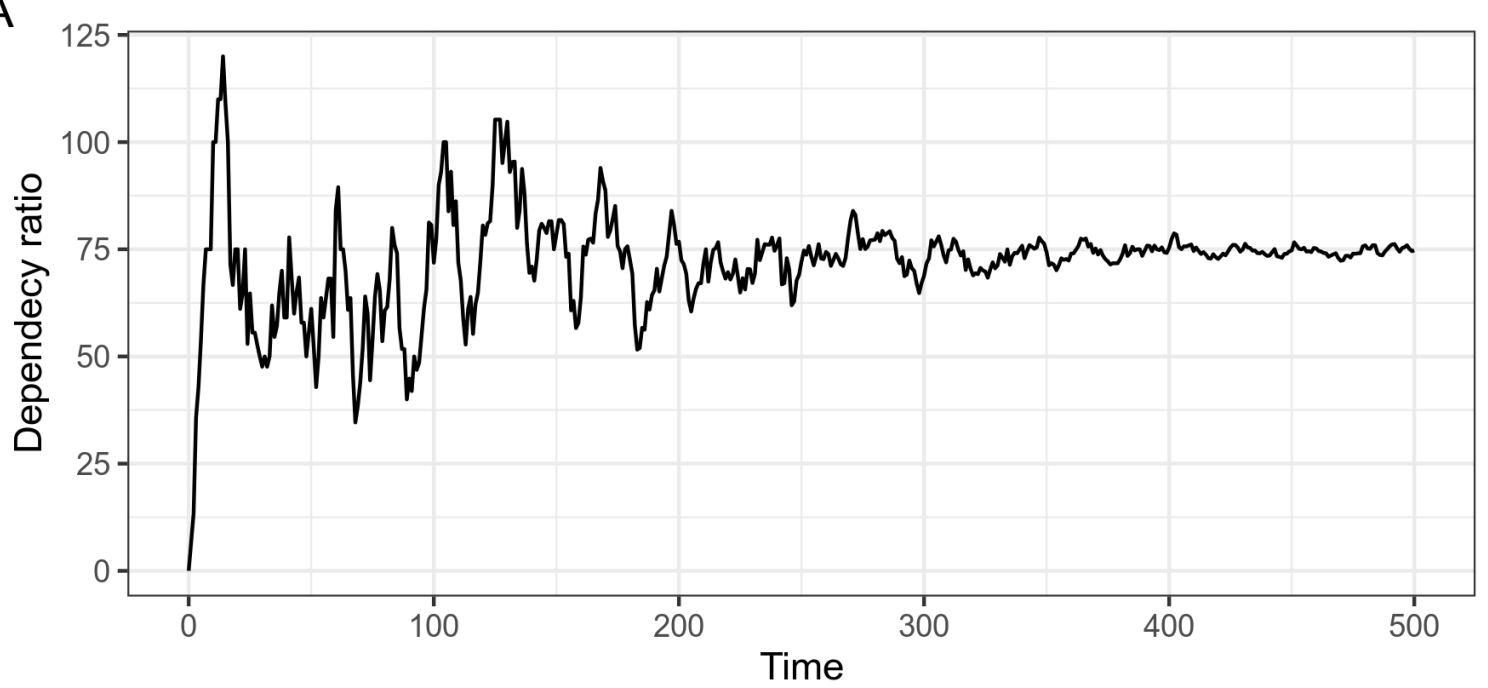

B
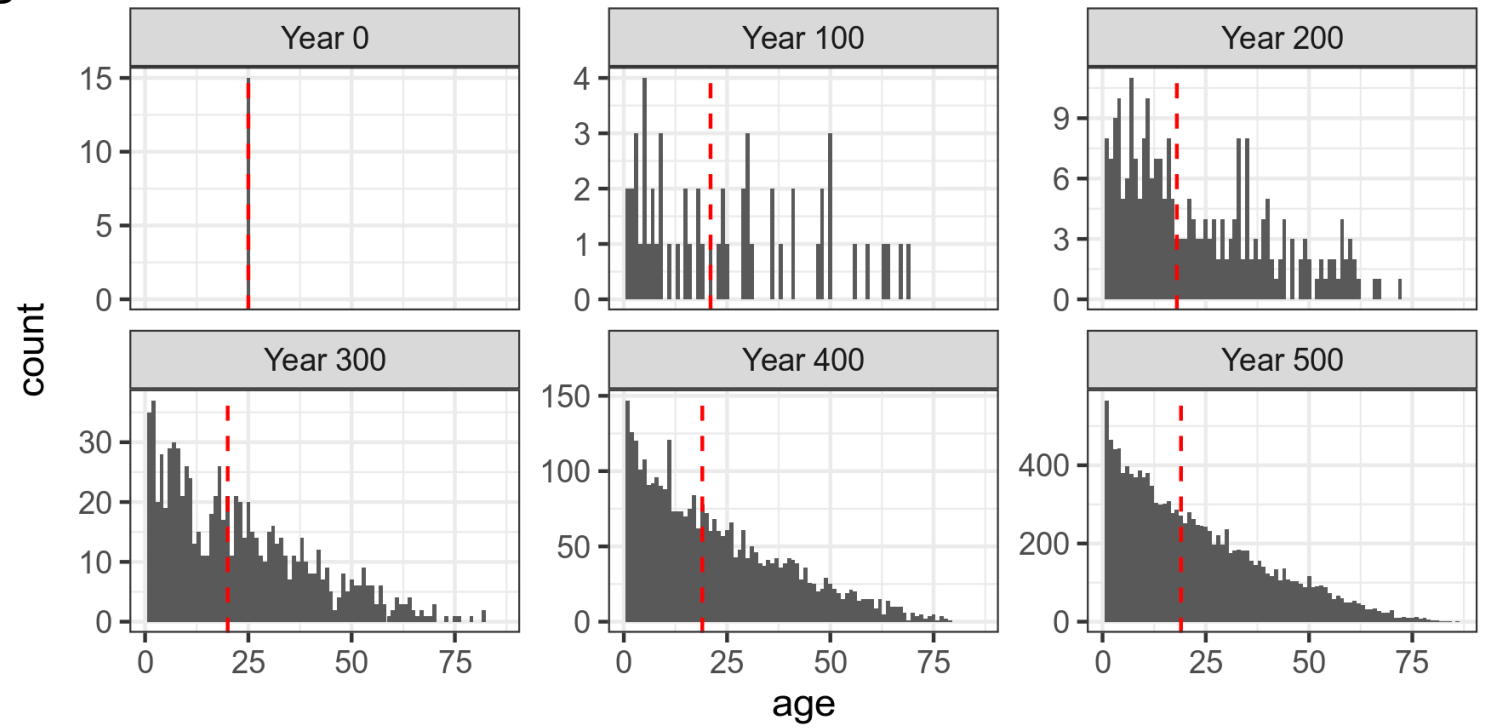

Figure 7: A. The ratio of food consumers to food produces over time in the absence of food limitation. From a starting population of 15 individuals aged 25 years, the population undergoes damped oscillations as it repeatedly overshoots then undershoots its equilibrium age structure of 75 , finally stabilizing in 300-400 years. B. The evolution of the age structure in A to a young and fast-growing equilibrium. Median age denoted in red. 

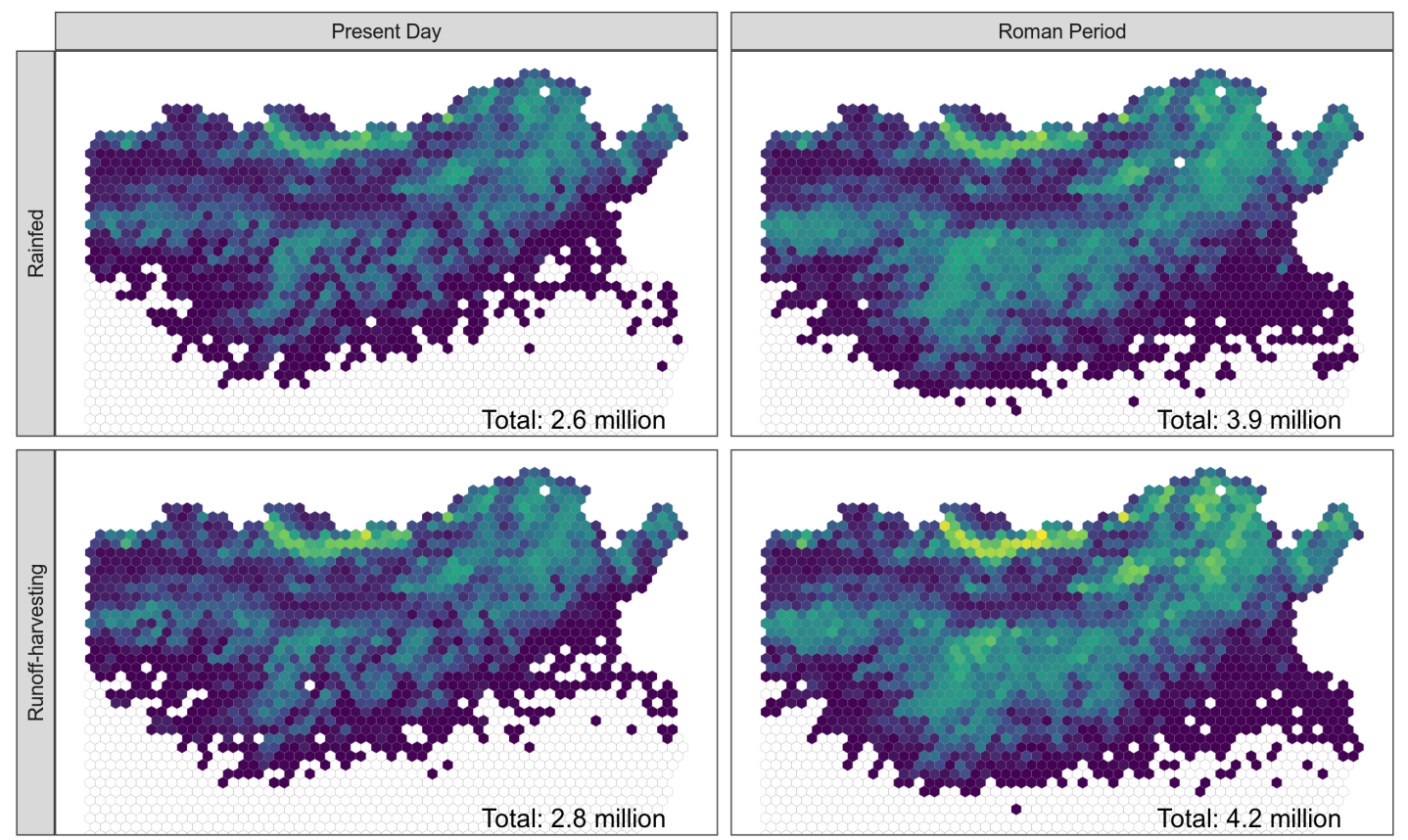

Population (thousands)

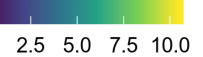

Figure 8: Simulated rural population equilibria in Roman North Africa, assuming no influences from urban centers or the greater Roman world. Four experimental scenarios are presented: with average annual rainfall at $200 \mathrm{CE}$ and present-day levels, and with and without local runoff-harvesting. 
tential rural population directly involved in food production, independent of external economic influences from urban centers or the broader Roman world. Although many factors determine the precise equilibrium point, the key variables that influence environmental carrying capacity are precipitation and the area of cultivable land. The carrying capacity varies linearly with cultivable area and nonlinearly with water availability.

The wetter conditions ca $200 \mathrm{CE}$ were able to support about $50 \%$ more rural population as could present-day conditions. Broadly, this increase in population was achieved by a southern movement of the habitable zone into the Atlas mountains and pre-desert steppe, rather than by intensification in existing zones. By contrast, local niche construction via runoff harvesting has a more modest impact on population, generally increasing population density in already inhabited regions rather than shifting the habitable zone. This result contrasts with previous suggestions that hydraulic infrastructure, not climate, played a critical role in maintaining high rural populations during the Roman period. In general, runoff harvesting is constrained by the available moisture supply. While the practice has marginal utility in regions already experiencing some rainfall it is less able to expand settlement in regions with extremely dry conditions.

\subsection{Regions of High Simulated Rural Population Correspond to Regions of Dense Roman-period Settlement}

Comparing these population estimates to the composite settlement pattern data (Bagnall 2018) from the Roman and pre-Roman periods (using $30 \mathrm{BCE}$ as a cutoff) allows for an assessment of the model's ability to generate the broad spatial patterns of Roman population distribution and to test whether the simulated dynamics are consistent with the empirical record (Figure 9). Overall, the simulated population density corresponds well to the location of known Roman settlements.

Simulated populations were highest in the coastal zones in the northern and eastern portion of the study region, reaching from 8,000 to 10,000 people per $5 \mathrm{~km}$ grid cell ( $65 \mathrm{~km}^{2}$, or roughly 150 people per $\mathrm{km}^{2}$ ). This area includes the hinterlands of major cities like Carthage and Hippo Reggius, as well as known agricultural regions like the Bagradas River valley. Populations of 2,000 to 8,000 people were sustainable further inland along a broad band trending from the northeast to the south central portion of the study area, corresponding to higherelevation zones in the Atlas mountains such as the Belezma Plain. The difference between the pre-Roman and Roman settlement patterns is striking, and clearly reflects expansion south consistent with the southerly extension of rainfall during the Roman period. In particular, a major difference of Roman and pre-Roman settlement is found in the Belezma plains in central zone of the study region, precisely where the model predicts an expansion of potential agricultural carrying capacity due to increased rainfall.

There are notable exceptions to the correspondence between simulated population and archaeological settlement patterns, however, particularly in pre-Sahara region in the south of the domain and the semi-arid step zone in the southeast. Indeed, the model generally underestimates this southern expansion of settlement during the Roman period. Archaeological sites in these areas generally correspond to local springs, oases, or regions with intermittent streamflow - potential sources of irrigation water not represented in the model. Settlements in the semiarid southeast of the study domain may also have relied on olive cultivation to provide extra food calories and economic benefits, also not included in the present version of 
A
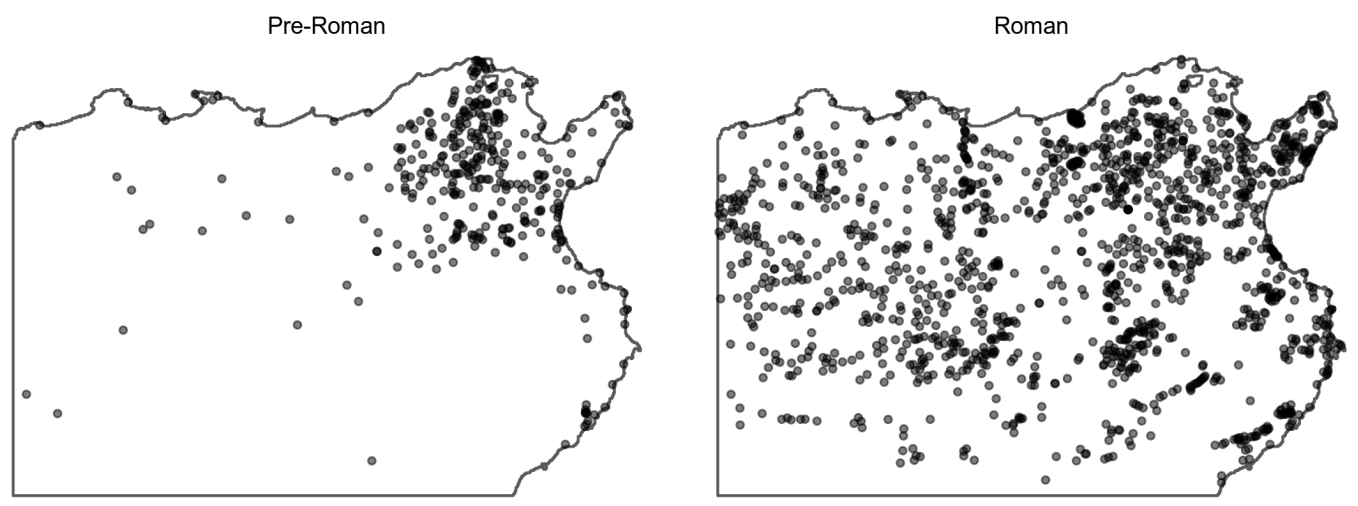

B

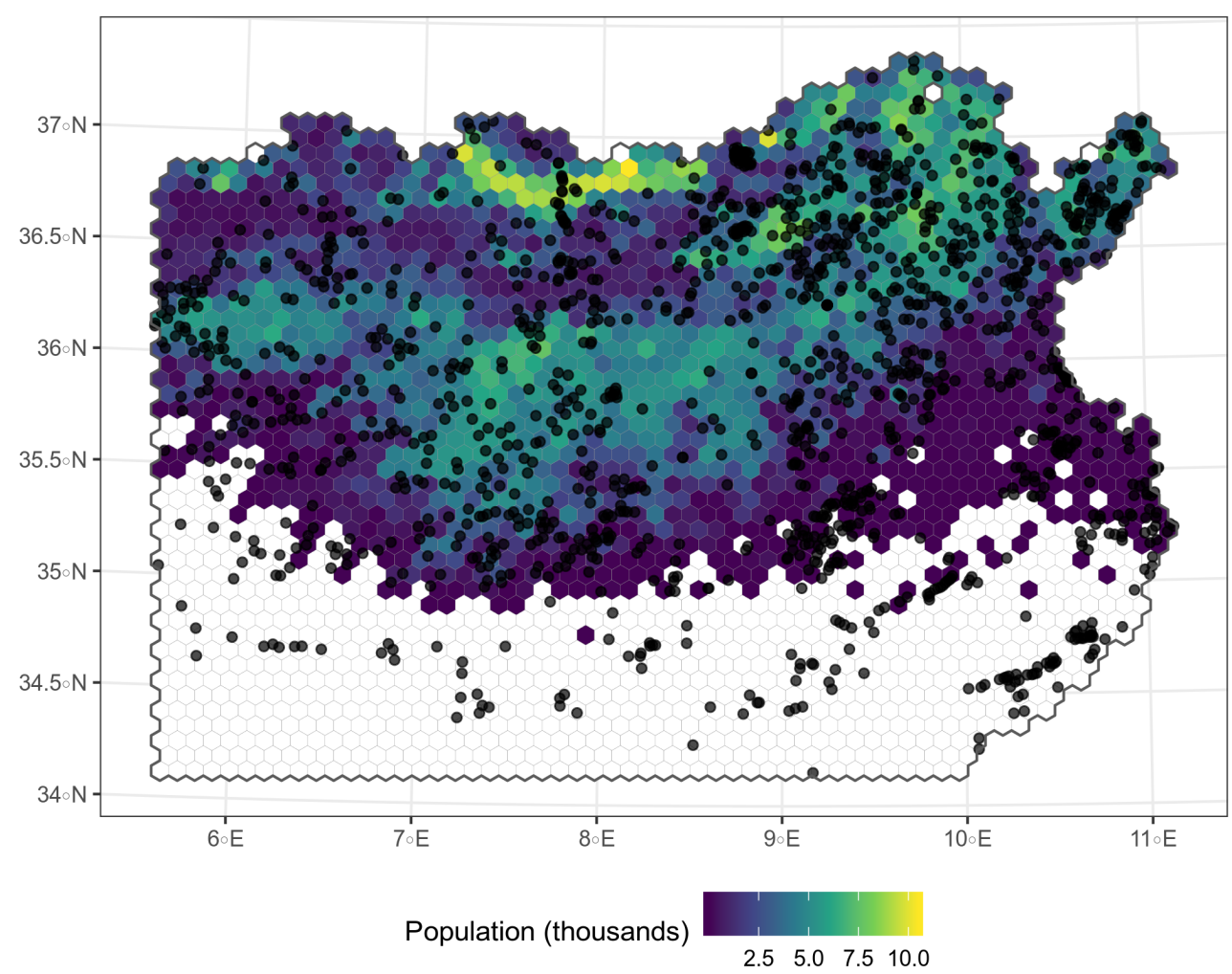

Figure 9: A) Settlement patterns in North Africa, before and after 30 BCE (Bagnall 2018). Initial settlements clustered in the north east of modern-day Tunisia near the city of Carthage, and expanded inland to the semi-arid steppe and pre-desert zone during the Roman period. B) Roman-period settlement patterns overlain on simulated rural populations supported by runoff harvesting and rainfall at $200 \mathrm{CE}$. Regions of high productivity generally correspond to denser settlement, including in well-documented breadbasket regions, and settlements beyond the productive land are associated with more specialized irrigation systems or olive cultivation. 
the model. Also of note is the paucity of archaeological sites in the northern coastal strip where the model predicts the highest carrying capacity. This region receives a large amount of rainfall to this day and remains well-vegetated, so perhaps archaeological sites are hidden under vegetation or modern development.

\section{Discussion}

Overall, these results suggest the first principles underlying the model are able to generate realistic emergent patterns. Intrinsic growth rates match those attested during short-run periods of high population growth in the archaeological record (Cowgill 1975). Populations grow quickly to their demographic saturation point, and the mechanisms of food-limitation curtail growth in a few short generations before demographic saturation occurs (Puleston et al. 2014). External shocks to fertility or mortality are quickly absorbed by renewed population growth, as long as the demographic saturation point remains fixed (Watkins and Menken 1985). Instabilities in the age structure can lead to oscillations as the population returns to equilibrium. The exact location of this point is determined by land availability and agricultural productivity (Fanta et al. 2018b), which in turn are influenced by the social and technological factors internal to the population (Wood 1998).

In the case of Roman North Africa, the model echoes findings from independent geomorphic proxy records that climate change played a primary role in North African environmental history, and that anthropogenic factors were important but secondary (Faust et al. 2004). Increased rainfall at ca $200 \mathrm{CE}$ explains much of the increased sustainable rural population in North Africa, save for in the driest pre-desert zones where unmodeled irrigation or agropastoral practices appear to have been more important. Major breadbasket regions attested in the historical and archaeological records, such as the Bagradas River valley and the Belezma plains (Kehoe 1988; Mattingly and Hitchner 1995), correspond to areas of high estimated agricultural carrying capacity in the simulation. Areas in the simulation where there are sharp boundaries between more and less productive land generally correspond to breaks or clusters in archaeological settlement pattern data (Bagnall 2018).

As is generally the case when modeling complex systems, a collection of simple, interacting modules is preferable to an overly-detailed model of a single process that fails to capture the relevant interactions. I have thus prioritized breadth over depth in this model by relying on existing algorithms and conceptual implementations where available - no matter how simple - in order to ensure the main processes are represented. In this study, I have presented a modeling framework that acts as a first step towards a more precise representation of population dynamics in the past. The model can now act as a baseline for successive iterations, allowing us to focus our attention on the specific submodules, state variables, and parameters that are most crucial for the operation of the system as a whole. Future work will focus on currently unexplored factors that will increase or decrease population growth rates, as well as unexpected external shocks.

This model currently resolves only rural agricultural settlement. Additional work will also focus on elaborating the land use portion of the model, including adding functionality for multiple crop types (e.g. barley, pulses, olives, and grapes) (Dermody et al. 2014), as well as the rearing of sheep and goat in more extensive pastoral production systems (Ullah 2011; Barton et al. 2012). Although food resources are removed from each household to represent taxation and other food redistribution mechanisms, at present this food leaves the system 
entirely. Future elaborations of this model will redirect these resources to feed distinct elite and urban populations who are not primary food producers. The sublinear or superlinear scaling of population density to food supply can also be explored (Qubbaj et al. 2014). Elite agent food requirements will scale superlinearly with population, reflecting more extravagant lifestyles, but a proportion of the food resources will also be reinvested into social and physical infrastructure that can temporarily increase the rural carrying capacity. Having two such populations will allow for the exploration of structural-demographic cycles arising from mismatched growth rates and bidirectional feedbacks between these two populations (Turchin 2003). The non elite urban population will exhibit sublinear scaling of food requirement with population, reflecting efficiencies in urban living (Hanson et al. 2017). This approach will also allow for a fuller exploration of inter-urban trade and migration in the Roman world using existing transport models (Scheidel et al. 2012).

The goal of this study was not to recreate Roman North Africa in detail. Rather, it was to present the conceptual and methodological framework for using multilevel simulation to generate land-use and demographic estimates for premodern agrarian societies of up to millions of people. Roman North Africa provides a concrete illustration of the possibilities of this approach. The multilevel simulation approach presented here can be generalized to other agricultural societies in space and time. The model was designed to be as general as possible, with all details relating to the Roman case study executed via parameterizations stored in static configuration files. New configuration files can be developed to represent other societies, clearing a path to broader cross-cultural comparisons.

\section{References}

Avissar, R. and Pielke, R. A. (2002). A Parameterization of Heterogeneous Land Surfaces for Atmospheric Numerical Models and Its Impact on Regional Meteorology.

Bagnall, R. (2018). Pleiades: A Gazetteer of Past Places.

Barton, C. M., Ullah, I., and Mitasova, H. (2012). Computational Modeling and Neolithic Socioecological Dynamics: A Case Study from Southwest Asia. American Antiquity, $75(2): 364-386$.

Beckers, B., Berking, J., and Schütt, B. (2013). Ancient Water Harvesting Methods in the Drylands of the Mediterranean and Western Asia. eTopoi: Journal for Ancient Studies, $2: 145-164$.

Benson, L. V., Berry, M. S., Jolie, E. A., Spangler, J. D., Stahle, D. W., and Hattori, E. M. (2007). Possible impacts of early-11th-, middle-12th-, and late-13th-century droughts on western Native Americans and the Mississippian Cahokians. Quaternary Science Reviews, 26(3):336-350.

Bevan, A., Colledge, S., Fuller, D., Fyfe, R., Shennan, S., and Stevens, C. (2017). Holocene fluctuations in human population demonstrate repeated links to food production and climate. Proceedings of the National Academy of Sciences, 114(49):E10524-E10531.

Bevan, A., Conolly, J., Colledge, S., Frederick, C., Palmer, C., Siddall, R., and Stellatou, A. (2013). The Long-Term Ecology of Agricultural Terraces and Enclosed Fields from Antikythera, Greece. Human Ecology, 41(2):255-272. 
Boserup, E. E. (1965). The Conditions of Agricultural Growth: The Economics of Agrarian Change under Population Pressure. Chicago Aldine, 1(1):124.

Butzer, K. W. (2012). Collapse, environment, and society. Proceedings of the National Academy of Sciences, 109(10):3632âĂŞ3639.

Chayanov, A. V. (1986). The Theory of Peasant Economy. Manchester University Press.

Coale, A. J., Demeny, P. G., and Vaughan, B. (1983). Regional model life tables and stable populations. Academic Press, Inc., 2 edition.

Cowgill, G. L. (1975). On Causes and Consequences of Ancient and Modern Population Changes. American Anthropologist, 77(3):505-525.

Currie, T. E., Bogaard, A., Cesaretti, R., Edwards, N., Francois, P., Holden, P., Hoyer, D., Korotayev, A., Manning, J., Moreno Garcia, J. C., Oyebamiji, O. K., Petrie, C., Turchin, P., Whitehouse, H., and Williams, A. (2015). Agricultural Productivity in Past Societies: Toward an Empirically Informed Model for Testing Cultural Evolutionary Hypotheses. Cliodynamics, 6(1):24-56.

Danti, M. D. (2010). Late Middle Holocene Climate and Northern Mesopotamia: Varying Cultural Responses to the 5.2 and 4.2ka Aridification Events. In Mainwaring, A. B., Giegengack, R., and Vita-Finzi, C., editors, Climate Crises in Human History, pages 139-174.

de Sherbinin, A., VanWey, L. K., McSweeney, K., Aggarwal, R., Barbieri, A., Henry, S., Hunter, L. M., Twine, W., and Walker, R. (2008). Rural household demographics, livelihoods and the environment. Global Environmental Change, 18(1):38-53.

Dean, J. S. (1996). Demography, environment, and subsistence stress. In Tainter, J. A. and Tainter, B. B., editors, Evolving Complexity and Environmental Risk in the Prehistoric Southwest, pages 25-56. Addison-Wesley.

Dermody, B. J., De Boer, H. J., Bierkens, M. F. P., Weber, S. L., Wassen, M. J., and Dekker, S. C. (2012). A seesaw in Mediterranean precipitation during the Roman Period linked to millennial-scale changes in the North Atlantic. Climate of the Past, 8(2):637-651.

Dermody, B. J., Van Beek, R. P. H., Meeks, E., Klein Goldewijk, K., Scheidel, W., Van Der Velde, Y., Bierkens, M. F. P., Wassen, M. J., and Dekker, S. C. (2014). A virtual water network of the Roman world. Hydrology and Earth System Sciences, 18(12):5025-5040.

Dewar, R. E. (1984). Environmental Productivity, Population Regulation, and Carrying Capacity. American Anthropologist, 86(3):601-614.

Dunning, N. P., Beach, T., Grasiozo Sierra, L., Jones, J. G., Lentz, D. L., Luzzadder-Beach, S., Scarborough, V. L., and Smyth, M. P. (2013). A Tale of Two Collapses: Environmental variability and cultural disruption in the Maya Lowlands. Diálogo Andino, 41:171-183.

Fanta, V., Šálek, M., Zouhar, J., Sklenicka, P., and Storch, D. (2018a). Equilibrium dynamics of European preindustrial populations: The evidence of carrying capacity in human agricultural societies. Proceedings of the Royal Society B: Biological Sciences, 285(1871):20172500. 
Fanta, V., Šálek, M., Zouhar, J., Sklenicka, P., and Storch, D. (2018b). Equilibrium dynamics of European preindustrial populations: The evidence of carrying capacity in human agricultural societies. Proceedings of the Royal Society B: Biological Sciences, 285(1871).

Faust, D., Zielhofer, C., Baena Escudero, R., and Diaz Del Olmo, F. (2004). High-resolution fluvial record of late Holocene geomorphic change in northern Tunisia: Climatic or human impact? Quaternary Science Reviews, 23(16-17):1757-1775.

Fuller, D., van Etten, J., Manning, K., Castillo, C., Kingwell-Banham, E., Weisskopf, A., Qin, L., Sato, Y., and Hijmans, R. (2011). The contribution of rice agriculture and livestock pastoralism to prehistoric methane levels: An archaeological assessment. The Holocene, 21(5):743-759.

Garnsey, P. (1989). Famine and Food Supply in the Graeco-Roman World: Responses to Risk and Crisis. Cambridge University Press.

Gates, L. D. and Ließ, S. (2001). Impacts of deforestation and afforestation in the Mediterranean region as simulated by the MPI atmospheric GCM. Global and Planetary Change, $30(3-4): 309-328$.

Hanson, J. W., Ortman, S. G., and Lobo, J. (2017). Urbanism and the division of labour in the Roman Empire. Journal of the Royal Society Interface, 14(136).

He, F., Vavrus, S. J., Kutzbach, J. E., Ruddiman, W. F., Kaplan, J. O., and Krumhardt, K. M. (2014). Simulating global and local surface temperature changes due to Holocene anthropogenic land cover change. Geophysical Research Letters, 41(2):623-631.

Hilali, A. (2013). Rome and Agriculture in Africa Proconsularis: Land and Hydraulic Development. Revue belge de philologie et d'histoire, 91(1):113-125.

Hughes, J. D. (2011). Ancient Deforestation Revisited. Journal of the History of Biology, $44(1): 43-57$.

Hunt, C. O. and Rabett, R. J. (2014). Holocene landscape intervention and plant food production strategies in island and mainland Southeast Asia. Journal of Archaeological Science.

Kaniewski, D., Van Campo, E., Guiot, J., Le Burel, S., Otto, T., and Baeteman, C. (2013). Environmental Roots of the Late Bronze Age Crisis. PLoS ONE, 8(8):e71004.

Kaplan, J. O., Krumhardt, K. M., Ellis, E. C., Ruddiman, W. F., Lemmen, C., and Goldewijk, K. K. (2010). Holocene carbon emissions as a result of anthropogenic land cover change. Holocene, 21(5):775-791.

Kaplan, J. O., Krumhardt, K. M., and Zimmermann, N. (2009). The prehistoric and preindustrial deforestation of Europe. Quaternary Science Reviews, 28(27-28):3016-3034.

Kaptijn, E. (2015). Irrigation and human niche construction. An example of socio-spatial organisation in the Zerqa Triangle, Jordan. Water History, 7(4):441-454.

Kehoe, D. P. (1988). The economics of agriculture on Roman imperial estates North Africa. Vandenhoeck and Ruprecht. 
Klein Goldewijk, K., Beusen, A., Doelman, J., and Stehfest, E. (2017). New anthropogenic land use estimates for the Holocene; HYDE 3.2, Earth Syst. Sci. Data Discuss., doi, 10:927-953.

Koch, A., Brierley, C., Maslin, M. M., and Lewis, S. L. (2019). Earth system impacts of the European arrival and Great Dying in the Americas after 1492. Quaternary Science Reviews, 207:13-36.

Lansing, J. S. and Fox, K. M. (2011). Niche construction on Bali: The gods of the countryside. Philosophical Transactions of the Royal Society B: Biological Sciences, 366(1566):927-934.

Latiri, K., Lhomme, J. P., Annabi, M., and Setter, T. L. (2010). Wheat production in Tunisia: Progress, inter-annual variability and relation to rainfall. European Journal of Agronomy, $33(1): 33-42$.

Lawrence, D., Philip, G., Hunt, H., Snape-Kennedy, L., and Wilkinson, T. J. (2016). Long Term Population, City Size and Climate Trends in the Fertile Crescent: A First Approximation. Plos One, 11(3):e0152563.

Lee, C. T. and Tuljapurkar, S. (2008). Population and prehistory I : Food-dependent population growth in constant environments. Theoretical Population Biology, 73:473-482.

Lee, R. D. . (1987). Population Dynamics of Humans and Other Animals. Demography, 24(4):443-465.

Mattingly, D. J. and Hitchner, R. B. (1995). Roman Africa: An archaeological review. The Journal of Roman Studies, 85:165-213.

Murphey, R. (1951). The decline of North Africa since the Roman occupation: Climatic or human? Annals of the Association of American Geographers, 41(2):116-132.

Nooren, K., Hoek, W. Z., Dermody, B. J., Galop, D., Metcalfe, S., Islebe, G., and Middelkoop, H. (2018). Climate impact on the development of Pre-Classic Maya civilisation. Climate of the Past, 14(8):1253-1273.

Puleston, C., Tuljapurkar, S., and Winterhalder, B. (2014). The Invisible Cliff: Abrupt Imposition of Malthusian Equilibrium in a Natural-Fertility, Agrarian Society. PLoS ONE, $9(1): 1-13$.

Puleston, C. O. and Tuljapurkar, S. (2008). Population and prehistory II: Space-limited human populations in constant environments. Theoretical Population Biology, 74(2):147160.

Qubbaj, M. R., Shutters, S. T., and Muneepeerakul, R. (2014). Living in a Network of Scaling Cities and Finite Resources. Bulletin of Mathematical Biology, 77(2):390-407.

Read, D. W. and Leblanc, S. A. (2003). Population Growth, Carrying Capacity, and Conflict. Current Anthropology, 44(1):59-85.

Reale, O. and Dirmeyer, P. (2000). Modeling the effects of vegetation on Mediterranean climate during the Roman Classical Period. Part I: Climate history and model sensitivity. Global and Planetary Change, 25(3-4):163-184. 
Reale, O. and Shukla, J. (2000). Modeling the effects of vegetation on Mediterranean climate during the Roman Classical Period: Part II. Model simulation. Global and Planetary Change, 25(3-4):185-214.

Roberts, C. N., Woodbridge, J., Palmisano, A., Bevan, A., Fyfe, R., and Shennan, S. (2019). Mediterranean landscape change during the Holocene: Synthesis, comparison and regional trends in population, land cover and climate. Holocene, 29(5):923-937.

Scheidel, W., Meeks, E., and Weiland, J. (2012). ORBIS : The Stanford Geospatial Network Model of the Roman World. pages 1-56.

Shaw, B. D. (1982). Lamasba: an ancient irrigation community. Antiquités africaines, 18:61103.

Shennan, S., Downey, S. S., Timpson, A., Edinborough, K., Colledge, S., Kerig, T., Manning, K., and Thomas, M. G. (2013). Regional population collapse followed initial agriculture booms in mid-Holocene Europe. Nature Communications, 4:2486.

Simon, H. A. (1962). THE ARCHITECTURE OF COMPLEXITY. 106(6).

Simon, H. A. (1990). Bounded Rationality. In Utility and Probability, pages 15-18. Palgrave Macmillan UK, London.

Stone, D. (1998). Culture and investment in the rural landscape: the North African bonus agricola. Antiquités africaines, 34:103-113.

Stone, D. L. (1997). The development of an imperial territory: Romans, Africans, and the transformation of the rural landscape of Tunisia. PhD thesis, The University of Michigan.

Turchin, P. (2003). Historical dynamics: why states rise and fall. Princeton University Press.

Ullah, I. I. T. (2011). A GIS method for assessing the zone of human-environmental impact around archaeological sites: A test case from the Late Neolithic of Wadi Ziql??b, Jordan. Journal of Archaeological Science, 38(3):623-632.

Watkins, S. C. and Menken, J. (1985). Famines in Historical Perspective. Population and Development Review, 11(4):647-675.

White, K. D. (1965). The Productivity of Labour in Roman Agriculture. Antiquity, 39(154):102-107.

Wilkinson, T. J., Rayne, L., and Jotheri, J. (2015). Hydraulic landscapes in Mesopotamia: the role of human niche construction. Water History, 7(4):397-418.

Winterhalder, B., Puleston, C., and Ross, C. (2015). Production risk , inter-annual food storage by households and population-level consequences in seasonal prehistoric agrarian societies. Association for Environmental Archaeology, 20(4):337-348.

Wood, J. W. (1998). A Theory of Preindustrial Population Dynamics. Current Anthropology, 39(1):99-135.

Wright, D. K. (2017). Humans as Agents in the Termination of the African Humid Period. Frontiers in Earth Science, 5(January):1-14. 
Yu, D. J., Qubbaj, M. R., Muneepeerakul, R., Anderies, J. M., and Aggarwal, R. M. (2015). Effect of infrastructure design on commons dilemmas in social-ecological system dynamics. Proceedings of the National Academy of Sciences, 112(43):13207-13212.

\section{Affiliation:}

Nicolas Gauthier

Laboratory of Tree-Ring Research \&

School of Geography and Development

University of Arizona

Tucson, Arizona

E-mail: ngauthier@email.arizona.edu

URL: https://nick-gauthier.github.io 